\title{
PENGARUH DOSIS PEMUPUKAN N TERHADAP KUALITAS BIJI KAKAO DI PUNUNG PACITAN
}

\author{
Riris Rahayu Utami ${ }^{1)}$, Djoko Purnomo ${ }^{2)}$, Mercy Bientri Yunindanova ${ }^{2)}$ \\ 1) Mahasiswa S1 Program Studi Agroteknologi, Fakultas Pertanian,Universitas Sebelas Maret \\ 2) Staf Pengajar Program Studi Agroteknologi, Fakultas Pertanian,Universitas Sebelas Maret \\ Author Contact: ${ }^{2)}$ djpuruns@gmail.com
}

\begin{abstract}
Punung is a village in Pacitan Regency which potentiall for cultivating of cocoa, on the contrary it produces low seeds quality. This condition is caused by unintensive fertilization and low light intensity caused by shading. The effort to increase cocoa seed quality was by light compensation and the use of nitrogen $(\mathrm{N})$ fertilizer. The purpose of this reseach was to determine of optimum $\mathrm{N}$ dosage fertilizer for inproving seed quality. The research was arranged in Completely Randomized Block Design with one factor which is the varies $\mathrm{N}$ dosages ( 0 as control, 820 , 870 , and 920 gram plant $^{-1}$ year $\left.{ }^{-1}\right)$, level of radiation represented as blocks. Nitrogen fertilization was applicated three times. Fertilization of $\mathrm{P}(\mathrm{SP} 36)$ and $\mathrm{K}(\mathrm{KCl}), 1390$ and $1000 \mathrm{gram}^{-1}$ tree $^{-1}$ year ${ }^{-1}$ respectively. The observation variables are soil character, micro climate, leaf anatomi, physical and chemical seed quality. The result showed that $\mathrm{N}$ fertilizer influenced positively toward increasing potassium $(\mathrm{K})$ content in leaf tissue on the first and second month, while on the third month no significant influence toward $\mathrm{N}, \mathrm{P}$ and $\mathrm{K}$ content. However there was preference of increased N, P and $\mathrm{K}$ content in leaf tissue on each month although in small rise number. In the leaves tissue, there was detected that nitrogen proportion was larger than potassium and phosphorus. $\mathrm{N}$ fertilizer increased the physical and chemical seed quality (protein and fat content). Optimum dosage was 870 gram tree $^{-1}$ year $^{-1}$, highest weight of 100 seed (146 gram) and seed quality was categorized as grade 1.
\end{abstract}

Keywords: Nitrogen Fertilizer; Seed Physical Quality; Seed Chemical Quality

AGROTECHNOLOGY RESEARCH JOURNAL

Utami RR, Purnomo D, Yunindanova MB. 2018. Pengaruh dosis pemupukan N terhadap kualitas biji kakao di Punung Pacitan. Agrotech Res J 2(2): 41-46.

Utami RR, Purnomo D, Yunindanova MB. 2018. Effect $N$ fertilizer toward cocoa seed quality in Punung, Pacitan. Agrotech Res J 2(2): 41-46.

\section{PENDAHULUAN}

Kakao merupakan salah satu komoditas penting di Indonesia, menempati peringkat ketiga sebagai penyumbang devisa negara (Suryani dan Zulfbriansyah 2007). Produksi kakao Indonesia pada tahun 2016 sebanyak 760.429 ton dengan luas tanam 951.901 ha (Ditjenbun 2015). Tahun 2002 Perum Perhutani mengembangkan budidaya kakao di Punung untuk meningkatkan kesejahteraan petani sebagai perkebunan rakyat. Hampir seluruh pertanaman kakao di lahan pekarangan bercampur dengan berbagai komoditas antara lain kopi, mahoni, dan jati. Petani menggunakan teknologi budidaya sederhana (terutama pemupukan) ditambah dengan cahaya di bawah optimum (ternaungi pohon lain) sehingga produktivitas dan kualitas rendah.

Upaya mengatasi intensitas cahaya rendah bagi tanaman dapat melalui pengaturan pertanaman (jarak tanam dan manipulasi tajuk penaung) atau kompensasi penambahan nitrogen $(\mathrm{N})$. Nitrogen selain berperan menyediakan nutrisi bagi tanaman, juga berfungsi membentuk dan meningkatkan jumlah klorofil. Intensitas cahaya rendah memerlukan klorofil b lebih tinggi sebagai antena penangkap cahaya (Taiz et al. 2015). Peningkatan penangkapan cahaya diharapkan dapat meningkatkan fotosintat sehingga kualitas biji dapat meningkat sesuai standar nasional. Penelitian ini bertujuan untuk mempelajari pengaruh peningkatan pupuk $\mathrm{N}$ beserta dosis optimum untuk mengatasi cahaya rendah guna meningkatkan kualitas biji kakao.

${ }^{\star}$ Fak. Pertanian UNS Surakarta

JI. Ir. Sutami 36 A Surakarta

\section{BAHAN DAN METODE}

Penelitian dilaksanakan bulan Maret - Agustus 2017 menggunakan pertanaman kakao umur 3-4 tahun di lahan pekarangan di tiga dukuh Desa Punung (Jatisari, Klepu 1 dan Klepu 2), Kecamatan Punung, Kabupaten Pacitan, Jawa Timur dengan posisi geografi $08^{\circ} 07^{\prime} 10^{\prime \prime}$ LS dan $111^{\circ} 01^{\prime} 83^{\prime \prime}$ BT, serta elevasi 1209 sampai 1268 meter di atas permukaan laut (menggunakan GPS Garmin Oregon 550t). Percobaan faktor tunggal dengan dosis pupuk $N 820,870,920$ gram pohon ${ }^{-1}$ tahun $^{-1}$ dan kontrol menggunakan Rancangan Acak Kelompok (RAK) tiga ulangan dan perbedaan intesitas cahaya sebagai blok. Pemupukan $N$ (Urea) secara bertahap yaitu saat panen (Maret), pembentukan bunga (April), dan pembentukan buah (Mei). Penambahan pupuk $\mathrm{P}\left(\mathrm{SP}_{36}\right)$ dan $\mathrm{K}(\mathrm{KCl})$ dengan dosis 1390 dan 1000 gram pohon $^{-1}$ tahun $^{-1}$ (dosis standar) diberikan pada masing-masing pohon. Tanah dicangkul dengan radius $50-75 \mathrm{~cm}$ dari batang pokok kemudian pupuk ditebarkan secara melingkar di rizosfer. Pengamatan iklim mikro meliputi intensitas cahaya di atas tajuk pohon penaung, di atas dan bawah kakao menggunakan Digital Lightmeter 401025 Extech, suhu dan kelembaban udara menggunakan Thermo Hygrometer Digital, Isolab. Data pengamatan dianalisis menggunakan uji $\mathrm{F}$ (Analysis of Variance/ANOVA) taraf $5 \%$ menggunakan software SPSS, dan dilakukan uji lanjut dengan Duncan's Multiple Range Test (DMRT $5 \%)$.

Pengamatan karakter tanah sebelum pemupukan dan analisis jaringan daun dilakukan di Laboratorium Kimia dan Kesuburan Tanah Fakultas Pertanian, Universitas Sebelas Maret dengan parameter analisis 
tanah kandungan $\mathrm{N}$ total dengan metode Kjeldahl, $\mathrm{P}$ tersedia dengan metode Olsen, $\mathrm{K}$ tertukar dan Kapasitas Tukar Kation/KTK dengan metode ekstraksi $\mathrm{NH}_{4} \mathrm{Oac} 1 \mathrm{~N} \mathrm{pH} 7,0$, C organik dan Bahan Organik dengan metode Walkley \& Black, dan $\mathrm{pH}$ dengan metode Elektrode glass. Analisis jaringan daun meliputi kandungan $\mathrm{N}, \mathrm{P}$, dan $\mathrm{K}$. Analisis biji kakao dilaksanakan di Laboratorium Teknologi Pangan Fakultas Pertanian, Universitas Sebelas Maret dengan parameter kualitas fisik dan kualitas kimia meliputi kandungan protein, lemak dan polifenol.

\section{HASIL DAN PEMBAHASAN}

\section{Kondisi umum lokasi penelitian}

Suhu rata-rata ketiga lokasi penelitian berkisar 29$30^{\circ} \mathrm{C}$ dan kelembaban udara $65 \%-70 \%$ (Tabel 1) menunjukkan bahwa lokasi penelitian mendekati suhu optimum bagi kakao $\left(30-32^{\circ} \mathrm{C}\right)$ (Rubiyo dan Siswanto 2012). Suhu bagi kakao berhubungan erat dengan ketersediaan air, sinar matahari, dan kelembaban. Suhu sangat berpengaruh pada pembentukan flush atau tunas muda, pembungaan dan kerusakan daun. Demikian pula kelembaban udara bagi kakao kelembaban udara optimum sekitar $70-80 \%$. Ojo (2010) menyatakan bahwa kelembaban udara berkaitan dengan penyebaran penyakit, pengeringan dan penyimpanan hasil panen.

Intensitas cahaya antar lokasi dalam rancangan penelitian sebagai blok (Jatisari, Klepu 1 dan Klepu 2) tidak berbeda nyata. Rerata intensitas cahaya pada 3 lokasi penelitian yang diterima oleh kakao sebesar 5.043 lux atau $6,34 \%$ dari cahaya langsung (79.546 lux) mengakibatkan proses fotosintesis kakao di bawah optimum. Hal ini menunjukkan bahwa naungan terhadap kakao oleh pohon di pekarangan merupakan masalah untuk diatasi.Tingkat kesuburan tanah (sedang) cukup sesuai untuk budidaya kakao, namun sebagai upaya peningkatkan produktivitas dan kualitas kakao serta untuk mengatasi kendala seperti intensitas cahaya rendah maka diperlukan peningkatan pupuk. Pemupukan merupakan tindakan penambahan unsur hara untuk memperbaiki dan meningkatkan kesuburan tanah (Suarjana 2015). Pemupukan secara berimbang spesifik lokasi berguna untuk menentukan takaran (dosis), waktu, dan jenis pupuk yang tepat sehingga pertumbuhan dan produktivitas tanaman optimum.

Berdasarkan analisis tanah (Tabel 2) menunjukkan bahwa harkat kesuburan tanah di Desa Punung termasuk kategori sedang ( N, P tersedia, KTK dan C organik termasuk kategori sedang, sedangkan $\mathrm{K}$ tertukar termasuk kategori rendah). Semakin tinggi KTK maka tingkat kesuburan tanah semakin baik karena jumlah kation tersedia dan tertukar semakin tinggi (Anita dan Susilo 2012). Kandungan BO tinggi dan $\mathrm{pH}$ mendekati netral karena beraneka vegetasi yang terdapat di pekarangan sehingga terjadi akumulasi seresah. Kemasaman tanah berkategori netral sehingga semua unsur hara tersedia bagi tanaman. Kadar bahan organik tinggi $(>3 \%)$ dan nilai pertumbuhan kakao (Rubiyo dan Siswanto 2011). Kakao tumbuh dengan baik pada tanah dengan kadar bahan organik tinggi (Ditjenbun 2011). Tabel 2 merupakan hasil analisis kimia tanah sebelum pemupukan di Desa Punung.

Tabel 1 Iklim Mikro di Desa Punung

\begin{tabular}{cccccccc}
\hline & & \multicolumn{3}{c}{ Maksimum } & \multicolumn{2}{c}{$\begin{array}{c}\text { Minimum } \\
\text { Intensitas Cahaya } \\
\text { Tempat }\end{array}$} & Pengamatan
\end{tabular}

Keterangan: Waktu pengamatan pukul 10.00-12.00 WIB. Pengamatan 1, 2, 3, dan 4 dilakukan pada bulan Maret, April, Mei dan Juni 
Tabel 2 Hasil analisis kimia tanah di Desa Punung

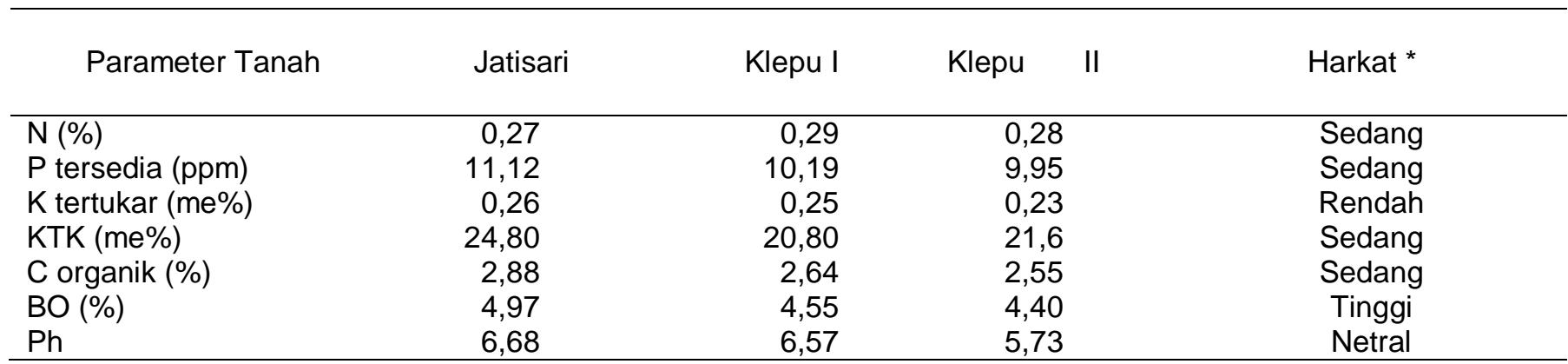

${ }^{*}$ Pengharkatan berdasarkan Balai Penelitian Tanah 2005

Serapan hara pada jaringan daun dan kandungan $\mathbf{N}$, $P$ dan $\mathrm{K}$ pada jaringan daun

Aplikasi pupuk $\mathrm{N}$ dengan dosis yang berbeda pada bulan pertama berpengaruh sangat nyata terhadap kandungan $\mathrm{K}$ dalam jaringan daun kakao. Hasil yang sama juga ditunjukkan pada bulan kedua. Hasil analisis jaringan daun (Tabel 3 dan 4) menunjukkan bahwa pupuk $\mathrm{N}$ berhubungan dengan kandungan $\mathrm{K}$. Dash et al. (2015) menyatakan bahwa terjadi hubungan sinergis antara pupuk $\mathrm{N}$ dan kandungan $\mathrm{K}$ dalam jaringan daun. Penyerapan nitrogen dalam bentuk nitrat (NO3-) merangsang serapan kalium $\left(\mathrm{K}^{+}\right)$. Hal tersebut terjadi karena pertukaran ion antara $\mathrm{NO}^{-}$yang berfungsi sebagai penyedia anion selama penyerapan atau pengangkutan $\mathrm{K}^{+}$(Sitienei et al. 2013). Hubungan yang berbeda dikemukakan oleh Hendrival et al. (2014) bahwa peningkatan konsentrasi kalium pada jaringan tanaman dapat menurunkan kandungan nitrogen terutama pada jaringan floem.

Tabel 3 Pengaruh pupuk N, P, dan K terhadap jaringan daun (bulan I)

\begin{tabular}{lccc}
\hline $\begin{array}{l}\text { Dosis urea } \\
\text { (gram pohon }^{-1} \text { ) }\end{array}$ & $\mathrm{N}(\%)$ & $\mathrm{P}(\%)$ & $\mathrm{K}(\%)$ \\
\hline 0 & 1,95 & 0,58 & $1,24^{\mathrm{a}}$ \\
820 & 1,33 & 0,59 & $1,27^{\mathrm{a}}$ \\
870 & 2,04 & 0,59 & $1.35^{\mathrm{b}}$ \\
920 & 2,06 & 0,58 & $1,37^{\mathrm{b}}$ \\
\hline Rerata & 1,85 & 0,58 & 1,31 \\
\hline
\end{tabular}

Keterangan: Dosis pupuk SP-36 $=1390$ dan $\mathrm{KCl}=1000$ gram pohon $^{-1}$

Tabel 4 Pengaruh pupuk N, P dan K terhadap jaringan daun (bulan II)

\begin{tabular}{lccc}
\hline $\begin{array}{l}\text { Dosis urea } \\
\text { (gram pohon }^{-1} \text { ) }\end{array}$ & $\mathrm{N}(\%)$ & $\mathrm{P}(\%)$ & $\mathrm{K}(\%)$ \\
\hline 0 & 1,92 & 0,65 & $1,18^{\mathrm{a}}$ \\
820 & 2,04 & 0,66 & $1,38^{\mathrm{b}}$ \\
870 & 2,04 & 0,70 & $1,41^{\mathrm{b}}$ \\
920 & 2,05 & 0,74 & $1,49^{\mathrm{b}}$ \\
\hline Rerata & 2,01 & 0,69 & 1,37 \\
\hline
\end{tabular}

Keterangan: Dosis pupuk SP-36 $=1390$ dan $\mathrm{KCl}=1000$ gram pohon $^{-1}$

Tabel 5 Pengaruh pupuk N, P dan K terhadap kandungan jaringan daun (bulan III)

\begin{tabular}{lccc}
\hline $\begin{array}{l}\text { Dosis urea } \\
\left.\text { (gram pohon }^{-1}\right)\end{array}$ & $\mathrm{N}(\%)$ & $\mathrm{P}(\%)$ & $\mathrm{K}(\%)$ \\
\hline 0 & 2,33 & 0,75 & 1,35 \\
820 & 2,59 & 0,71 & 1,41 \\
870 & 2,48 & 0,77 & 1,46 \\
920 & 2,50 & 0,77 & 1,55 \\
\hline Rerata & 2,48 & 0,75 & 1,44 \\
\hline
\end{tabular}

Keterangan: Dosis pupuk SP-36 $=1390$ dan $\mathrm{KCl}=1000$ gram pohon $^{-1}$

Perbedaan dosis $\mathrm{N}$ pada pemupukan bulan ketiga (Tabel 5) tidak berpengaruh nyata terhadap kandungan $\mathrm{N}, \mathrm{P}$ dan $\mathrm{K}$ jaringan daun. Hal tersebut karena terjadi penumpukan $\mathrm{N}$ pada profil tanah dari pemupukan sebelumnya dan sifat pupuk urea sebagai sumber $\mathrm{N}$ mudah hilang karena penguapan sehingga $\mathrm{N}$ belum terserap optimal oleh tanaman (Sidabutar 2013). Tanaman menyerap $\mathrm{N}$ dari Urea dalam bentuk $\mathrm{NO}_{3}$ atau $\mathrm{NH}_{4}{ }^{+}$sekitar $27-40 \%$ berarti sekitar $44-54 \%$ hilang melalui penguapan. Sedangkan $\mathrm{P}$ dan $\mathrm{K}$ digunakan oleh tanaman untuk membentuk organ generatif (bunga dan buah). Penelitian pada tanaman Plantago coronopus menunjukkan bahwa pada fase reproduktif dari $100 \%$ nutrisi yang diberikan, $41 \%$ digunakan untuk proses reproduktif sedangkan $59 \%$ digunakan untuk pembentukan akar dan daun (Koelewijn 2004). 
Peningkatan kandungan unsur hara pada jaringan daun

Rata-rata kandungan $\mathrm{N}, \mathrm{P}$, dan $\mathrm{K}$ dalam daun kakao pada semua perlakuan (bulan I, II, dan III) masing-masing 2,13, 1,37 dan 0,67\%. Ini menunjukkan bahwa kandungan $\mathrm{N}$ daun paling tinggi di antara $\mathrm{P}$ dan
K. Penelitian Rusek et al. (2014) pada gandum juga menunjukkan bahwa pemupukan $\mathrm{N}$ dan $\mathrm{P}$ mengakibatkan kandungan $\mathrm{N}$ daun lebih tinggi daripada P. Gambar 1, 2, 3, dan 4 sebagai gambaran kandungan $\mathrm{N}, \mathrm{P}$ dan $\mathrm{K}$ dalam daun per bulan.

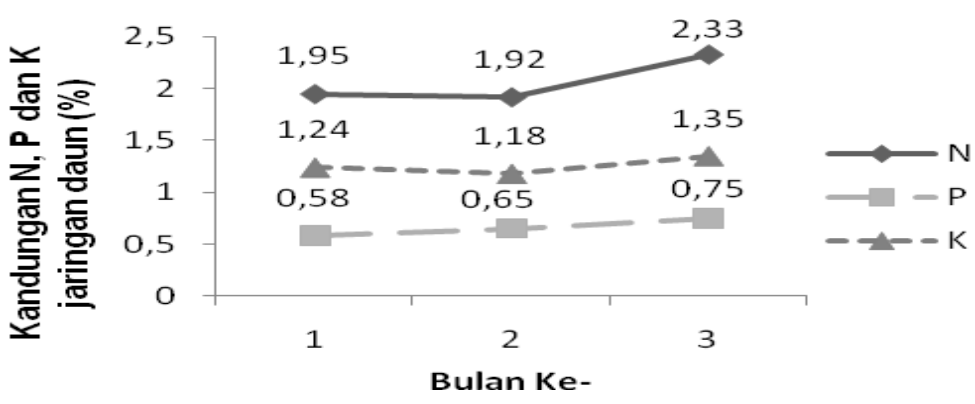

Gambar 1 Kandungan N, P dan K pada jaringan daun kakao dengan dosis urea: 0 gram pohon $^{-1}$

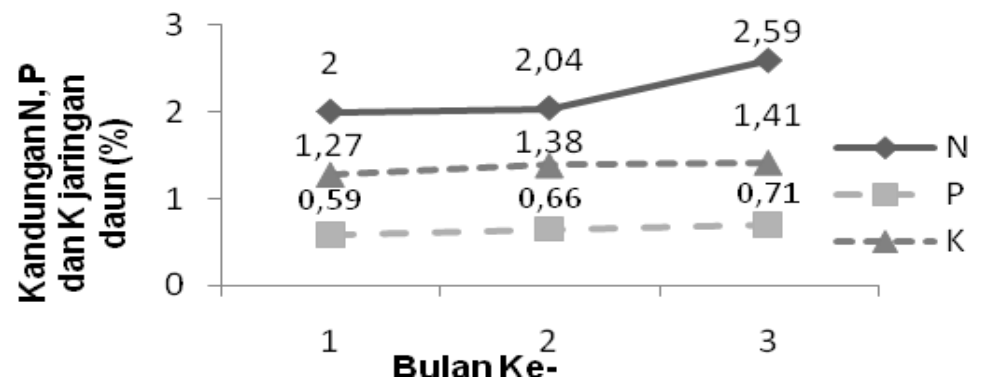

Gambar 2 Kandungan N, P dan K pada jaringan daun kakao dengan dosis urea: 820 gram pohon $^{-1}$

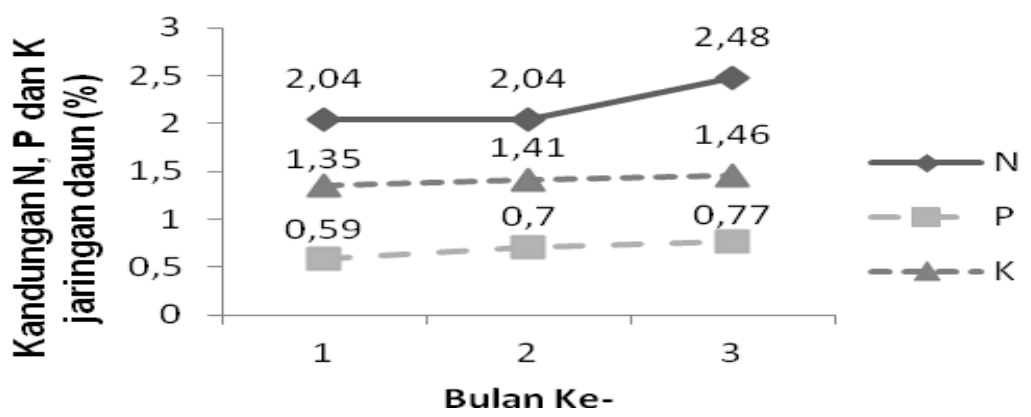

Gambar 3 Kandungan N, P dan K pada jaringan daun dengan dosis urea : 870 gram pohon $^{-1}$

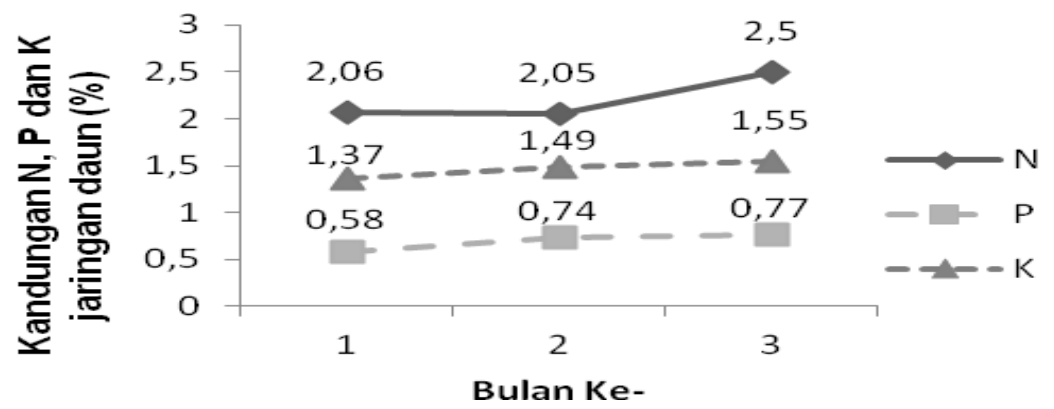

Gambar 4 Kandungan N, P dan K pada jaringan daun dengan dosis urea : 920 gram pohon $^{-1}$ 
Peningkatan kandungan $\mathrm{N}$ pada semua dosis sebesar $0,5 \%$. Hasil menunjukkan bahwa pemupukan tidak berpengaruh signifikan terhadap kenaikan kandungan N daun. Penelitian Oyewole et al. (2012) menunjukkan hasil sama yaitu pemupukan $\mathrm{N}$ pada kakao tidak berpengaruh signifikan terhadap kandungan $\mathrm{N}$ daun. Hal tersebut dapat dijelaskan bahwa pada tiga bulan setelah pemupukan $\mathrm{N}$ belum diserap optimal oleh kakao seperti penelitian Adil et al. (2006) pada sayuran menyatakan bahwa $\mathrm{N}$ berasal dari urea diserap pada 4 bulan pertama, selain itu terdapat dugaan lain bahwa $\mathrm{N}$ digunakan untuk pembentukan organ generatif seperti buah dan biji. Hal ini mengacu penelitian Liferdi et al. (2005) pada rambutan bahwa kandungan $\mathrm{N}$ daun turun saat fase generatif karena digunakan dalam pembentukan senyawa-senyawa lain seperti protein pada biji.

\section{Kualitas fisik biji kakao}

Dosis urea 870 gram pohon $^{-1}$ menghasilkan bobot 100 biji paling besar dan jumlah biji per 100 gram paling sedikit (Tabel 6) termasuk kualitas paling tinggi. Menurut Puslitkoka (2015) jumlah biji per 100 gram kurang dari 85 termasuk dalam kategori kualitas tinggi (AA), 86-100 biji/ 100 gram termasuk kategori A, 101$110 \mathrm{bij} / 100$ gram termasuk kategori $B, 111-120 \mathrm{biji} / 100$ gram termasuk kategori $C$ dan lebih dari 120 biji/ 100 gram termasuk kategori $S$ atau terendah. Dosis urea 0 , 820 dan 870 gram pohon $^{-1}$ masuk dalam kategori AA, sedangkan dosis 920 gram pohon $^{-1}$ termasuk kategori C.

Tabel 6 Pengaruh perlakuan dosis pemupukan terhadap kualitas fisik biji kakao

\begin{tabular}{lcccccc}
\hline $\begin{array}{l}\text { Dosis urea } \\
\left(\text { gram pohon }{ }^{-1}\right)\end{array}$ & Panjang $(\mathrm{cm})$ & $\begin{array}{c}\text { Lebar } \\
(\mathrm{cm})\end{array}$ & $\begin{array}{c}\text { Bobot Biji Per buah } \\
(\mathrm{gram})\end{array}$ & $\begin{array}{c}\text { Bobot 100 biji } \\
(\mathrm{gram})\end{array}$ & $\begin{array}{c}\text { Jumlah biji } \\
\text { per buah }\end{array}$ & $\begin{array}{c}\text { Jumlah } \\
\text { biji per } \\
100 \text { gram }\end{array}$ \\
\hline 0 & 1,95 & 1,1 & 33,1 & 122,6 & 27 & 82 \\
820 & 2,06 & 1,1 & 40,2 & 118,3 & 34 & 85 \\
870 & 2,31 & 1,3 & 51,1 & 146,0 & 35 & 68 \\
920 & 2,03 & 1,0 & 36,9 & 83,8 & 44 & 119 \\
\hline
\end{tabular}

Keterangan: Dosis pupuk $\mathrm{P}=1390 \mathrm{~g}_{\text {pohon }}{ }^{-1}$ dan pupuk $\mathrm{K}=1000 \mathrm{gram}_{\text {pohon }}{ }^{-1}$

Nitrogen berperan dalam proses pembentukan biji karena sebagai unsur utama protein. Protein merupakan komponen terbesar sel, lebih dari $50 \%$ berat kering. Adisarwanto (2005) menjelaskan bahwa N dari tanah diabsorpsi tertimbun di batang dan daun, pada proses pengisian biji sebagian besar $\mathrm{N}(80-85 \%)$ mengalami remobilisasi ke biji sehingga meningkatkan berat kering biji kedelai.

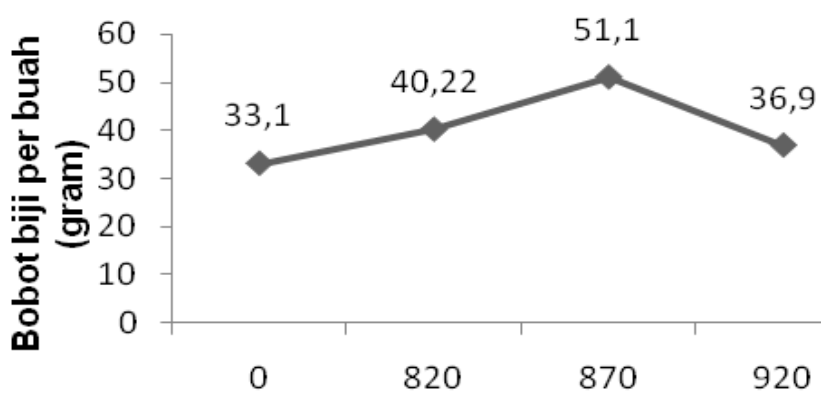

Dosis Pupuk urea (gram pohon-1)

Gambar 5 Grafik bobot biji per buah

Peningkatan bobot biji dari 33,1 gram menjadi 51,1 gram terjadi pada dosis 0 sampai 870 gram pohon $^{-1}$ kemudian turun menjadi 36,9 gram pada dosis 920 gram pohon $^{-1}$ (Gambar 5). Hasil tersebut menunjukkan dosis optimum untuk pertumbuhan biji yaitu 870 gram pohon $^{-1}$. Nitrogen diserap tanaman dalam bentuk $\mathrm{NO}^{-}$dan $\mathrm{NH}^{+}$. Penyerapan nitrogen yang optimum membuat proses metabolisme tanaman berjalan dengan baik. Ketersediaan $\mathrm{N}$ dan cahaya selama pertumbuhan tanaman meningkatkan fotosintat. Akumulasi fotosintat di bagian vegetatif tanaman pada fase geberatif antara lain untuk pengisian biji sehingga bobot biji meningkat.
Pupuk $\mathrm{N}$ dosis 920 gram pohon ${ }^{-1}$ meningkatkan pertumbuhan vegetatif ( $\mathrm{N}$ tinggi) namun menghambat laju pertumbuhan generatif yaitu penurunan bobot biji. Menurut Malhi et al. (2002) bahwa pemupukan N melebihi kebutuhan tanaman dapat mengakibatkan akumulasi nitrat (NO3-) pada profil tanah sehingga menghambat penyerapan nitrat oleh tanaman.

\section{Kualitas kimiawi biji kakao}

Kandungan protein, lemak dan polifenol sangat menentukan kualitas biji kakao. Tabel 7 menunjukkan terjadi peningkatan kandungan protein dan lemak setelah pemupukan N. Nitrogen berperan meningkatkan penyerapan cahaya dengan sintesis klorofil (b) sehingga dapat mengkompensasi intensitas cahaya rendah pada kakao. Peningkatan proses fotosintesis menghasilkan fotosintat kemudian disintesis menjadi senyawa-senyawa dalam biji kakao. Novizan (2004) menyatakan bahwa N berfungsi dalam pembentukan klorofil dan asam amino untuk diubah menjadi protein pada tanaman.

Tabel 7 Pengaruh dosis pupuk $\mathrm{N}$ pada kandungan protein, lemak, dan polifenol dalam biji

\begin{tabular}{lccc}
\hline $\begin{array}{l}\text { Dosis urea } \\
\text { (gram }^{-1}\end{array}$ & $\begin{array}{c}\text { Protein } \\
(\%)\end{array}$ & $\begin{array}{c}\text { Lemak } \\
(\%)\end{array}$ & $\begin{array}{c}\text { Polifenol } \\
(\%)\end{array}$ \\
\hline 0 & 21,35 & 46,34 & 6,27 \\
820 & 23,27 & 49,26 & 5,76 \\
870 & 21,76 & 49,26 & 5,61 \\
920 & 19,01 & 46,41 & 6,09 \\
\hline
\end{tabular}

Keterangan: Dosis pupuk SP-36 $=1390$ gram pohon $^{-1}$ dan pupuk $\mathrm{KCl}=1000 \mathrm{gram}_{\text {pohon }}{ }^{-1}$ 
Kandungan protein biji tertinggi pada dosis 820 gram pohon ${ }^{-1}$ sebesar $23,27 \%$, lemak tertinggi pada dosis 820 dan 870 gram pohon $^{-1}$ sebesar $49,26 \%$. Kandungan polifenol pada semua perlakuan sudah memenuhi standar umum yaitu $5-6 \%$ (Hill et al. 2009). Puslitkoka (2008) mensyaratkan kandungan protein $15 \%$ dan lemak $50-51 \%$ untuk biji kakao sebagai bahan baku produk cokelat. Kandungan protein sudah memenuhi persyaratan sedangkan lemak sedikit dibawah kriteria.

\section{KESIMPULAN DAN SARAN}

\section{KESIMPULAN}

Kesimpulan penelitian ini yaitu pemupukan nitrogen meningkatkan kualitas fisik dan kimia biji kakao di Punung, Pacitan. Dosis pupuk N (urea) optimum untuk meningkatkan kualitas fisik biji kakao yaitu 870 gram pohon $^{-1}$ tahun $^{-1}$, sedangkan kualitas kimia pada dosis 820 gram pohon $^{-1}$ tahun $^{-1}$.

\section{SARAN}

Upaya peningkatan kualitas dan kuantitas biji kakao bagi petani Punung, Pacitan disarankan menggunaan pupuk $\mathrm{N}$ (urea) dosis $870 \mathrm{~g}$ pohon ${ }^{-1}$ tahun $^{-1}$ dan melakukan pemangkasan naungan yang terlalu rapat agar intensitas cahaya yang diperoleh kakao dapat optimal.

\section{DAFTAR PUSTAKA}

Adil WH, Novianti S, Ika R. 2006. Pengaruh tiga jenis pupuk nitrogen terhadap tanaman sayuran. Biodiversiti 7(1): 77-80.

Adisarwanto. 2005. Kedelai. Penebar Swadaya: Jakarta.

Anita SI, Susilo AW. 2012. Keberhasilan sambungan beberapa jenis batang atas dan batang bawah kakao (Theobroma cacao L.). Pelita Perkebunan 28(2):75-84.

Dash A.K., Singh HK., Mahakud T, Pradhan K.C. and Jena D. (2015). Interaction Effect of Nitrogen, Phosphorus, Potassium with Sulphur, Boron and Zinc on Yield and Nutrient Uptake by Rice Under Rice - Rice Cropping System in Inceptisol of Coastal Odisha . Int. Res. J Agric. Sci. Soil Sci. 5(1):14-21

Ditjenbun. 2011. Statistika perkebunan Indonesia: kakao. Jakarta (ID): Direktorat Jenderal Perkebunan.

Ditjenbun. 2015. Statistika perkebunan Indonesia: kakao. Jakarta (ID): Direktorat Jenderal Perkebunan.

Hendrival, Latifa, Idawati. 2014. Pengaruh pemupukan kalium terhadap perkembangan populasi kutu daun (Aphis glycines matsumura) dan hasil kedelai. J Floratek. 9: 83 - 9 .

Hill CL, Law CL, Suzannah S, Misnawi, Cloke M. 2009. Polyphenols in cocoa (Theobroma cacao L.). As. J Food Ag-Ind. 2(04): 702-722.
Koelewijn HP. 2004. Rapid change in relative growth rate between the vegetative and reproductive stage of the life cycle in Plantago coronopus. New Phytologist 163: 67-76.

Liferdi, Poerwanto R, Darusman LK. 2005. Perubahan kandungan karbohidrat dan nitrogen 4 varietas rambutan. J Hort. 16(2): 134-141.

Malhi SS, Brandt SA, Ulrich D, Lemke R, Gill K. 2002. Accumulation and distribution of nitratenitrogen and extractable phosphorus in the soil profile under various alternative cropping systems. J Plant Nutr. 25: 2499-2520.

Novizan. 2004. Petunjuk pemupukan yang efektif. Jakarta (ID): Agromedia Pustaka

Ojo AD, lyanda S. 2010. Effect of climate change on cocoa yield: a case of cocoa research institute (crin) farm, oluyole local goverment ibadan oyo state. $J$ Suistainable Development In Africa. 2(1): 350-354.

Oyewole SO, Ajayi IOJ, Rotimi RI. 2012. Growth of cocoa (Theobroma cacao L.) seedlings on old cocoa soils amended with organic and inorganic fertilizers. African Journal of Agricultural Research. 7(24): 3604-3608.

Pusat Penelitian Kopi dan Kakao Indonesia. 2008. Budidaya Kakao. Jakarta (ID): Agromedia.

Rubiyo, Siswanto. 2011. Peningkatan produksi dan pengembangan kakao di Indonesia. RISTRI 3(1):3335.

Rubiyo, Siswanto. 2012. Inovasi teknologi perbaikan bahan tanam kakao di Indonesia. Buletin Riset Tanaman Rempah dan Aneka Tanaman Industri 4(3): 99-214.

Rusek P, Szymanska M, Karsznia M, Cholewa US, Igras J. 2016. The effectiveness of nitrogenphosphorus fertilization in winter wheat (triticum aestivum I.) cultivation. Bulgarian Journal of Agricultural Science. 22 (5) : 752-755.

Sidabutar SV, Siagian B, Meiriani. 2013. Respon pertumbuhan bibit kakao terhadap pemberian abu janjang kelapa sawit dan pupuk urea pada media pembibitan. Jurnal Online Agroteknologi 1(4): 13431351.

Sitienei K, Patrick GH, David MK, John KW. 2013. Nitrogen and potassium dynamics in tea cultivation as influenced by fertilizer type and application rates. American Journal of Plant Sciences. 4: 59-65.

Suarjana IW, Supadma AAN, Arthagama IDM. 2015. Kajian status kesuburan tanah sawah untuk menentukan anjuran pemupukan berimbang spesifik lokasi tanaman padi di kecamatan manggis. EJurnal Agroekoteknologi Tropika. 4(4): 314-316.

Suryani D, Zulfbriansyah. 2007. Komoditas kakao. Economic Review no.210. http://www.bni.co.id.

Taiz L, Zeiger E, lan MM. 2014. Plant physiology and development. Sunderland (U.S.A): Sinauer Assoociates. 